\title{
Research on the Impact of Internet Finance on Systematic Risks of Commercial Banks
}

\author{
Ming Xiao \\ School of Management \\ Wuhan University of Technology \\ Wuhan 430070, China
}

\begin{abstract}
The rapid development of Internet finance has profoundly affected China's financial structure. As the indirect financing of banks is the main financing channel for China's economy, the number of commercial banks and the depth and breadth of participation in economic activities far exceed those of brokers and insurance companies. Commercial banks were also the most affected when internal and external shocks came. Based on the literature review, this paper first summarizes the impact path of Internet finance on commercial banks and puts forward hypotheses. Secondly, this paper draws on the existing indicators, starting from the deposit and loan business, using SPSS for relevant analysis and found that the systematic risk of commercial banks is positively correlated with capital adequacy ratio, liquidity ratio, credit growth rate and non-performing loan ratio. Finally, this paper summarizes the existing research deficiencies and proposes possible future development directions.
\end{abstract}

Keywords—internet finance; commercial banking; systemic risk; conduction path

\section{INTRODUCTION}

In recent years, Internet finance has developed rapidly. New financial products and tools such as Alipay, WeChat Payment, Renren Loan, and Wukong Wealth have emerged in an endless stream, profoundly changing the financial structure of China and creating an unprecedented business for commercial banks. Great impact from 2010, P2P online lending companies have sprung up. Third-party payment companies have obtained third-party payment licenses issued by the central bank. By June 2013, Alipay and Tianhong Fund jointly launched Yu'ebao. In the financial market, the thirdparty payment platform has been aggressively expanding its trading scale and directly impacting the commercial bank deposit business, which has put the commercial bank's earnings at risk of being eroded. According to the statistics of analysis, the scale of third-party Internet payment transactions in China reached 24.54 trillion Yuan in 2017. According to the statistics of China Fund News, as of the end of June 2018, the total scale of 6 fund funds of Yu'ebao has reached 18602 Billion Yuan has increased by more than 280 billion Yuan. Compared with the balance of Yu'ebao at the end of 2017, which increases close to $18 \%$. It can be seen that the rapid development of Internet finance has become an indisputable fact, and its impact on the financial market cannot be underestimated.

The development of Internet finance will have a major impact on China's commercial banks: in the case of demand deposits in the deposit business, in the long run, third-party payments will affect the bank deposit structure and lead to an increase in bank capital costs. As far as the loan business is concerned, compared to the bank's strict qualification review of the borrower, Internet finance can rely on the big data thirdparty payment institution to obtain the information of the small and micro enterprise; due to different customer sources,in the long run, there will be problems of mutual competition in the loan business, Internet finance and banking. As far as the intermediary business is concerned, the Internet online payment replaces the traditional credit card settlement, and the conflict of interest caused by this cannot be ignored. At the same time, due to the technological innovation, openness and other characteristics of Internet finance, the related policies are lagging behind and the implementation of supervision is not in place, its impact on the risks of commercial banks cannot be ignored. Therefore, studying the factors affecting the systemic risk of commercial banks has important practical significance for commercial banks to maintain their competitiveness under the impact of Internet finance and to achieve stable, coordinated and sustainable development of China's financial system.

\section{LITERATURE REVIEW}

\section{A. Research on the impact of internet finance on commercial} banks

Scholars have different views on the impact of Internet finance on commercial banks. Some scholars believe that the development of Internet finance can have a positive impact on commercial banks. Wu Xiaoqiu believes that the Internet and the financial system are coupled with the four basic functions of resource allocation, payment settlement, risk allocation and bidding mechanism, which will further optimize these functions and lead to the "deep" reform of the financial system [1]. Lapavitsas and Dos Santos believe that Internet finance brings about technological innovations that help to alleviate the information asymmetry between banks and borrowers, thus contributing to bank risk management [2].But some other scholars believe that the development of Internet finance will have a negative effect on commercial banks. With the development of information technology, Internet finance will gradually replace online banking. Foreign scholars compare Internet finance with traditional commercial banks. They find that Internet financial loans are faster than commercial banks and can enjoy relatively low loan interest rates and Internet 
finance loans has an impact on the traditional banking industry [3]. Similarly, Internet finance will aggravate the systemic risks of China's banking industry, and the impact will exist for a long time. The continuous expansion of Internet finance will still impact the macro economy and increase the risk of China's banking system [4].

\section{B. Research on the Impact of Internet Finance on Systematic Risks of Commercial Banks' Core Business}

1) For loan business: The development of Internet finance has brought severe challenges to the development of traditional commercial banks, resulting in the gradual reduction of the advantages of traditional commercial banks in the loan business, the loss of loan customers, and the reduction of payment of settlement fees. The impact of the decline in agency business and other impacts, the growth rate of traditional commercial banks also showed a certain decline [5]. Yang Xingjian points out that Internet finance has impacted the credit efficiency of commercial banks. The online lending platform represented by P2P provides credit services for small and medium-sized enterprises and individuals through big data risk control technology. Although the transaction size of individual users is small, the huge amount of small and medium-sized enterprises and individual needs are combined to create profits and it has formed the long tail of the Internet financial market [6].

2) For deposit business: Li Penglin, Dong Yiyi believes that commercial banks are the source of P2P online loan funds, and P2P online loans will take away commercial bank deposits [7]. On the one hand, the Internet financial property relies on the low-cost Internet platform to gather a large number of investors and funds through the long tail effect, resulting in the transfer of a large number of demand deposits of commercial banks and enhancing the liquidity risk of commercial banks. On the other hand, there is a maturity mismatch between the assets and liabilities of Internet finance, which has liquidity risk and may become a systemic risk source in the economy [8].

In summary, it can be known that Internet finance can affect commercial banks through the deposit and loan business. In the empirical analysis part, we will start from this aspect and select indicators that can represent the deposit business, loan business and the systematic risks of commercial banks, then carry out empirical analysis and finally draw relevant conclusions.

\section{RESEARCH HYPOTHESIS}

Liu Zhiyang sums up the predecessors' view that liquidity risk indicators have an impact on deposit and loan business, and liquidity ratio indicators can reflect liquidity risk indicators. Credit risk is an important part of the capital adequacy ratio of commercial banks. Therefore, nonperforming loan ratio indicators are introduced to reflect loan credit risk. Through empirical research, he finds that the combination of liquidity ratio index and capital adequacy index can effectively control the commercial bank systemic risk [9]. Yang Min believes that the change in credit growth rate can accurately reflect the expansion and contraction of credit supply. Bank systemic risk can be reflected by M2/GDP,
Shanghai Composite Index, GDP growth rate, and inflation rate [10].

Based on the research results of the above scholars, we propose the following hypothesis:

H1: M2/GDP has a positive correlation with capital adequacy ratio, liquidity ratio, credit growth rate, and nonperforming loan ratio.

H2: The Shanghai Composite Index has a positive correlation with capital adequacy ratio, liquidity ratio, credit growth rate and non-performing loan ratio.

H3: GDP growth rate is positively correlated with capital adequacy ratio, liquidity ratio, credit growth rate, and nonperforming loan ratio.

H4: There is a positive correlation between inflation rate and capital adequacy ratio, liquidity ratio, credit growth rate, and non-performing loan ratio.

\section{EMPIRICAL ANALYSIS}

We use capital adequacy ratio, liquidity ratio, credit growth rate, and non-performing loan ratio to represent the deposit and loan business of commercial banks. We use M2/GDP, Shanghai Composite Index, GDP growth rate, and inflation rate to represent the systematic risks of commercial banks. In this way, we have obtained the key factors affecting the systemic risk of commercial banks. We produced and distributed questionnaires to the management students and bank staff, and used SPSS to analyze the reliability, validity and correlation of the data. The results are as follows:

\section{A. Trust Level Analysis}

TABLE I. RELIABILITY TEST OF COMMERCIAL BANK SYSTEMIC RISK AND DEPOSIT LOAN BUSINESS INDICATORS

\begin{tabular}{|c|c|c|c|}
\hline \multicolumn{4}{|c}{ Cronbach Trust Level Analysis } \\
\hline name & $\begin{array}{c}\text { Correction item total } \\
\text { relevance(CITC) }\end{array}$ & $\begin{array}{c}\text { Item deleted } \\
\text { alpha coefficient }\end{array}$ & $\begin{array}{c}\text { Cronbach } \\
\text { alpha } \\
\text { coefficient }\end{array}$ \\
\hline $\begin{array}{c}\text { Capital } \\
\text { adequacy ratio }\end{array}$ & 0.655 & 0.927 & \\
\hline Liquidity ratio & 0.772 & 0.919 & \\
\hline $\begin{array}{c}\text { Credit growth } \\
\text { rate }\end{array}$ & 0.809 & 0.916 & \multirow{2}{*}{0.929} \\
\hline $\begin{array}{c}\text { Non-performing } \\
\text { loan ratio }\end{array}$ & 0.767 & 0.919 & \\
\hline M2/GDP & 0.754 & 0.921 & \\
\hline $\begin{array}{c}\text { Shanghai } \\
\text { Composite } \\
\text { Index }\end{array}$ & 0.752 & 0.916 & \\
\hline $\begin{array}{c}\text { GDP growth } \\
\text { rate }\end{array}$ & 0.808 & 0.921 & \\
\hline Inflation rate & 0.742 & \multicolumn{2}{|c|}{} \\
\hline
\end{tabular}

From the above table, we can see that the reliability coefficient value is 0.929 , which is greater than 0.9 , thus indicating that the research data reliability is very high. For the "alpha coefficient of item deleted", the reliability coefficient value after the analysis item is deleted has not been 
significantly improved, so the description items should all be retained, further indicating that the research data reliability level is high. For the "CITC value", the CITC values corresponding to the analysis items are all higher than 0.6 , thus indicating that there is a good correlation between the analysis items, and also indicating that the reliability level is good. In summary, the value of the reliability coefficient of the research data is higher than 0.9, and the reliability coefficient value after the deletion of the item is not significantly improved. The comprehensive description indicates that the data reliability is high and can be used for further analysis.

\section{B. Validity Analysis}

TABLE II. VALIDITY TEST OF SYSTEMATIC RISK AND DEPOSIT LOAN BUSINESS INDICATORS OF COMMERCIAL BANKS

\begin{tabular}{|c|c|c|c|}
\hline \multicolumn{4}{|c|}{ Validity Analysis Result } \\
\hline & \multicolumn{2}{|c|}{ Factor load factor } & \multirow{2}{*}{ Commonality } \\
\hline & Factor 1 & Factor 2 & \\
\hline Capital adequacy ratio & & 0.894 & 0.835 \\
\hline Liquidity ratio & & 0.808 & 0.81 \\
\hline Credit growth rate & & 0.681 & 0.764 \\
\hline Non-performing loan ratio & & 0.517 & 0.685 \\
\hline M2/GDP & 0.872 & & 0.82 \\
\hline Shanghai Composite Index & 0.743 & & 0.701 \\
\hline GDP growth rate & 0.652 & & 0.741 \\
\hline Inflation rate & 0.846 & & 0.781 \\
\hline $\begin{array}{c}\text { Characteristic root value (before } \\
\text { rotation) }\end{array}$ & 5.366 & 0.77 & - \\
\hline $\begin{array}{c}\text { Variance interpretation rate \% (before } \\
\text { rotation) } \square\end{array}$ & $67.079 \%$ & $9.628 \%$ & - \\
\hline $\begin{array}{c}\text { Cumulative variance interpretation } \\
\text { rate \% (before rotation) }\end{array}$ & $67.079 \%$ & $76.706 \%$ & - \\
\hline $\begin{array}{c}\text { Characteristic root value (after } \\
\text { rotation) } \\
\end{array}$ & 3.363 & 2.773 & - \\
\hline $\begin{array}{c}\text { Variance interpretation rate \% (after } \\
\text { rotation) } \quad \square\end{array}$ & $42.038 \%$ & $34.668 \%$ & - \\
\hline $\begin{array}{c}\text { Cumulative variance interpretation } \\
\text { rate } \% \text { (after rotation) }\end{array}$ & $42.038 \%$ & $76.706 \%$ & - \\
\hline KMO value $\quad \square$ & \multicolumn{2}{|c|}{0.889} & - \\
\hline 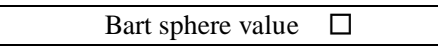 & \multicolumn{2}{|c|}{433.965} & - \\
\hline df $\quad \square$ & \multicolumn{2}{|c|}{28} & - \\
\hline p value $\square$ & \multicolumn{2}{|c|}{0} & - \\
\hline
\end{tabular}

Validity study is used to analyze whether the research items are reasonable and meaningful. The validity analysis uses factor analysis to analyze this data analysis method, and comprehensively analyzes the indicators such as KMO value, common degree, variance interpretation rate value and factor load coefficient value to verify the validity level of the data. The KMO value is used to judge whether the validity is valid, the common value is used to exclude the unreasonable research item, the variance interpretation rate value is used to describe the information extraction level, and the factor load coefficient is used to measure the factor and the item correspondence, from the above table. It can be seen that the common value corresponding to all the research items is higher than 0.4 , indicating that the research item information can be effectively extracted. In addition, the KMO value is 0.889 , which is greater than 0.6 , meaning that the data is valid. In addition, the variance interpretation rate values of the two factors were $42.038 \%$ and $34.668 \%$, respectively, and the cumulative variance interpretation rate after rotation was $76.706 \%>50 \%$, this means that the amount of information in the research item can be extracted efficiently.

\section{Correlation Analysis}

TABLE III. CORRELATION TEST BETWEEN SYSTEMATIC RISK OF COMMERCIAL BANKS AND DEPOSIT LOAN BUSINESS

\begin{tabular}{|c|c|c|c|c|}
\hline \multicolumn{5}{|c|}{ Pearson related - standard format } \\
\hline & M2/GDP & $\begin{array}{c}\text { Shanghai Composite } \\
\text { Index }\end{array}$ & $\begin{array}{l}\text { GDP growth } \\
\text { rate }\end{array}$ & $\begin{array}{l}\text { Inflation } \\
\text { rate }\end{array}$ \\
\hline $\begin{array}{l}\text { Capital adequacy } \\
\text { ratio }\end{array}$ & $0.457^{* *}$ & $0.579 * *$ & $0.552^{* *}$ & $0.407^{* *}$ \\
\hline Liquidity ratio & $0.547 * *$ & $0.553^{* *}$ & $0.659 * *$ & $0.616^{* *}$ \\
\hline Credit growth rate & $0.604^{* *}$ & $0.617^{* *}$ & $0.760^{* *}$ & $0.599 * *$ \\
\hline $\begin{array}{l}\text { Non-performing } \\
\text { loan ratio }\end{array}$ & $0.643 * *$ & $0.538 * *$ & $0.713^{* *}$ & $0.634 * *$ \\
\hline \multicolumn{5}{|c|}{$* \mathrm{p}<0.05 * * \mathrm{p}<0.01$} \\
\hline
\end{tabular}

From the above table, we can see:

M2/GDP and capital adequacy ratio, liquidity ratio, credit growth rate, and non-performing loan ratio all showed significantness. The correlation coefficient values were 0.457 , $0.547,0.604,0.643$, and the correlation coefficient values were greater than 0 , which means that there is a positive correlation between M2/GDP and capital adequacy ratio, liquidity ratio, credit growth rate and non-performing loan ratio.

The Shanghai Composite Index and the capital adequacy ratio, liquidity ratio, credit growth rate, and non-performing loan ratio all showed significantness. The correlation coefficient values were $0.579,0.553,0.617,0.538$, and the correlation coefficient values were greater than 0 , which means that there is a positive correlation between the Shanghai Composite Index and the capital adequacy ratio, liquidity ratio, credit growth rate and non-performing loan ratio.

The GDP growth rate and capital adequacy ratio, liquidity ratio, credit growth rate, and non-performing loan ratio all showed significantness. The correlation coefficient values were $0.552,0.659,0.760,0.713$, and the correlation coefficient values were greater than 0 , which means that there is a positive correlation between GDP growth rate and capital adequacy ratio, liquidity ratio, credit growth rate, and non-performing loan ratio.

The inflation rate and capital adequacy ratio, liquidity ratio, credit growth rate, and non-performing loan ratio all showed significantness. The correlation coefficient values were 0.407 , $0.616,0.599,0.634$, and the correlation coefficient values were greater than 0 , which means that there is a positive correlation 
between inflation rate and capital adequacy ratio, liquidity ratio, credit growth rate, and non-performing loan ratio.

\section{CONCLUSION}

In summary, there is still a lot of debate about the impact of Internet finance on commercial banks, and most of them are theoretical analysis, and there is very little quantitative analysis. Researches have almost not combined the current background of financial deleveraging, and lack mathematical evidence and theoretical speculation. Future research can quantify the impact of deleveraging and use empirical research methods to conduct quantitative research, so as to obtain a more systematic transmission mechanism and preventive path of Internet finance to systemic risks of commercial banks.

In addition, M2/GDP, Shanghai Composite Index, GDP growth rate, inflation rate and capital adequacy ratio, liquidity ratio, credit growth rate, and NPL ratio showed a positive correlation. Internet finance can affect the systemic risks of commercial banks through core businesses such as bank deposits and loans. Therefore, commercial banks should pay attention to China's monetary policy and other related policies, pay attention to the credit level of enterprises, establish a sound credit evaluation system, and make it develop rapidly, so that commercial banks and Internet finance can achieve a win-win situation.

\section{REFERENCES}

[1] Wu Xiaoqiu. Internet Finance: The Logic of Growth [J]. Finance and Trade, 2015, 36 (2): 5-15. (In Chinese)

[2] Lapavitsas C, Santos P L D . Globalization and Contemporary Banking: On the Impact of New Technology [J]. Contributions to Political Economy, 2008, 27(1): 31-56.

[3] Onay C, Ozsoz E. The Impact of Internet-Banking on Brick and Mortar Branches - The Case of Turkey [J]. Journal of Financial Services Research, 2013, 44(2): 187-204.

[4] Zhu Chen, Hua Guihong. The Impact of Internet Finance on Systematic Risks in China's Banking Industry--An Empirical Study Based on SCCA Model and Stepwise Regression Method[J].Financial Economics Research,2018,33(02):50 -59. (In Chinese)

[5] Huang Manjing. Research on the Impact of Internet Finance on Traditional Commercial Banks [D]. University of International Business and Economics, 2015. (In Chinese)

[6] Yang Xingjian. The impact of China's Internet finance on commercial banking business and its countermeasures [D]. Changchun University, 2017. (In Chinese)

[7] Li Penglin, Dong Yiyi. The Impact of Internet Finance on the Core Business of Commercial Banks-Based on Panel Data of China's Major Commercial Banks from 2006 to 2016 [J]. Finance and Accounting Monthly, 2018(10): 153-161. (In Chinese)

[8] Dai Guoqiang, Fang Pengfei. Regulatory Innovation, Interest Rate Marketization and Internet Finance[J]. Modern Economic Research, 2014(7): 64-67. (In Chinese)

[9] Liu Zhiyang. Can Liquidity Risk Supervision Effectively Reduce the Systematic Risk Contribution of Commercial Banks? Empirical Evidence from Chinese Listed Banks [J]. Southern Finance, 2018(11): 67-74. (In Chinese)

[10] Yang Min, Wu Yan. An Empirical Study on the Relationship between Credit Cycle and Bank Systematic Risk in China[J]. Journal of Beijing University of Posts and Telecommunications(Social Sciences Edition), 2013, 15(03): 66-73. (In Chinese) 